\title{
Ergenlerin Kişilerarası Problem Çözme Becerileri ve Empatik Eğilimlerinin Sahip Oldukları Değerler Açısından İncelenmesi
}

\author{
DOI: $10.26466 /$ opus.517581
}

*

\section{Selma Demir* - Bülent Dilmaç**}

*YL Öğrencisi, İstanbul Sabahattin Zaim Üniversitesi Eğitim Bilimleri Bölümü, İstanbul/ Türkiye E-Posta: selmademir1980@hotmail.com

ORCID: $\underline{0000-0003-2812-9175}$

** Prof. Dr., Necmettin Erbakan Üniversitesi A.K.E.F. Eğitim Bilimleri Bölümü Konya/ Türkiye

E-Posta: bulentdilmac@gmail.com

ORCID: $\underline{0000-0001-5753-9355}$

\section{Öz}

Bu araştırmanın amacı, ergenlerin kişilerarası problem çözme becerileri, empatik eğilimleri ve sahip oldukları değerler arasındaki yordayıcı ilişkiyi ortaya koymak ve bu ilişkiden hareketle oluşturulan yapısal eşitlik modeli test etmektir. Araştırmanın çalışma grubunu, 2016-2017 eğitim-öğretim yılında İstanbul il merkezinde çeşitli liselerde öğrenim görmekte olan $323 \mathrm{klz}$ ve 251 erkek olmak üzere toplam 574 öğrenci oluşturmuştur. Araştırmanın çalışma grubu tesadüfi örnekleme yöntemi ile seçilmiştir. Araştırmada öğrencilerin problem çözme becerilerini ölçmek amacıyla "Kişilerarası Problem Çözme Envanteri", empatik eğilimlerini belirlemek için "KA-S_Çocuk ve Ergenler için Empatik Eğilim Ölçeği", insani değerlerini belirlemek amacıyla da "İnsani Değerler Ölçeği" ve "Kişisel Bilgi Formu" kullanılmıştır. Ölçüm araçlarının uygulanması sonucu elde edilen verilerin analizi için "Yapısal Eşitlik Modeli" ne göre AMOS 16 Programı kullanılmıştır. Araştırmada elde edilen istatistiksel bulguların anlamlılı̆̆ .001 düzeyinde sınanmıştır. Ergenlerin kişileraraesı problem çözme becerisi ile sahip oldukları değerler arasında pozitif yönlü doğrusal bir ilişki olduğunu göstermektedir. Diğer bir ifadeyle ergenlerin sahip

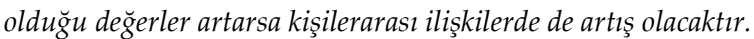

Anahtar Kelimeler: Ergen, kişilerarası problem çözme becerisi, empati, insani değer. 


\title{
Analysis of Interpersonal Problem Solving Skills and Empathic Tendencies of Adolescents
}

\begin{abstract}
The aim of the study is to present the predictor interrelation problem solving skills of the teenagers and the emphatetic tendency amongst the values they have and to test the model by means of this relation. The study group of the research consists of 574 students 323 of whom are girls and 251 of whom are boys attending different high-schools in central İstanbul throughout 2016-2017 academic year. The study group of the research has been chosen by random sampling method. In the study, in order to measvie the students ability of problem solving "Interrations Problem Solving Invantery", to identify their emphatetic tendency "KA-S_Emphatetic Tendency Scale For The Kids And Adults", to identify their humanitarian values "The Humanitarian Values Scale" and "Personal Data Form" has been used. To analyze the data as a result of the application of the measurement tools according to the "Structural Equality Model Amos 16 Programme has been used. The logic of the data abtained as a result of the statistical findings has been studied at the level of .001. According to the result of the study, the relationship between the interrelation problem solving skills and the emphatetic tendency of the teenagers has been found statistically meaningful. In terms of this, it can be said that the more the emphatetic tendency of the teenagers increases the more the interrelation problem solving skills increase. It has been found that there is a linear and positive relationship between the emphatetic tendency and values of the teenagers. In order words, if the values the teenagers have increase, there will be an increase in the interrelation, as well.
\end{abstract}

Keywords: Teenager, interrelation problem salving skill, empathy and humanitarian value. 


\section{Giriş}

Sosyal hayat içinde çevremizle sürekli iletişime geçmek durumundayız. Bu iletişim sürecinde, kurduğumuz ilişkilerde normal olarak zorluklarla ve problemlerle karşılaşabiliriz (Anlıak, Dinçer, 2005). Karşılaşılan bu problemler farklı derecelerde ve çeşitlilikte olabilirler. Bu problem çeşitleri birbirleriyle iç içe geçerek daha büyük ve karmaşık problemler haline dönüşebilirler (Cüceloğlu, 1997). Bu problemlerden biri olan kişiler arası problemde etkileşimde bulunulan taraflardan en az biri var olan etkileşim biçimi ile olması gereken etkileşim biçimi arasındaki farkı algılar ve bu fark yüzünden gerginlik hisseder, bu gerginliği ortadan kaldırmak için girişimde bulunduğunda engellenmeyle karşılaşır (Öğülmüş, 2006). İşte buradan da yola çıkarak kişiler arası problem çözmeyi, bireyin kişiler arası ilişkilerde içinde bulunduğu durum ile varmak istediği durum arasındaki farkın algılandığı ve bunun sebep olduğu gerginliği ortadan kaldırmak için çaba gösterilmesini içeren bilişsel ve davranışsal bir süreç olarak ifade edebiliriz (Öğülmüş, 2006). Bu süreç içinde, engelleri ortadan kaldırmak, bulunulan şartlara uyum sağlamak ve organizmayı bir iç dengeye kavuşturmak gibi etkinlikler yer alır (Öğ̈̈lmüş, 2001).

İnsanlar çocukluktan ergenliğe, ergenlikten yetişkinliğe kadar hayatlarında pek çok problemle karşılaşırlar. Her bireyin karşılaşılan problemle baş etme şekli kişilik özelliklerine göre farklılık göstermektedir. Bazı bireyler çözüm için etkili yollara başvururken bazıları da problem çözmede etkisiz olabilirler. Karşılaşılan bütün sorunlar, sağlıklı kişiler arası ilişkileri gerektirmekte ve insanların hayatlarını etkin ve uyumlu bir şekilde sürdürebilmeleri için de problem çözme becerilerini kullanmalarını zorunlu kılmaktadır (Yüksel, 2008).

Problem çözme 'bilişsel', 'duygusal' ve 'sosyal' yönden olmak üzere üç ayrı boyutta ele alınabilir. Bilişsel boyutta problemin kişi tarafından fark edilip, gerçek problemin bulunup çözümüyle ilgili farklı yolların ortaya konulması, çözüm yolları düzenlenmesi, en uygun çözüm yolunun bulunması ve tüm bunların bir bütün içinde ele alınması gibi bazı zihinsel süreçler yer alır. Duygusal boyutta ise özellikle kişiler arası problem çözmede bireylerin sağlıklı bir çözüme ulaşabilmeleri için hem kendi duygularını hem de karşısındaki kişinin duygularını iyi anlama ve doğru tepki- 
ler geliştirilmesi, aynı zamanda da problemi çözmede oluşabilecek gerilimle baş edebilme yer alır. Sosyal boyutta ise, uzman görüşüne başvurma, daha önce aynı problemle karşılaşan kişilerin nasıl başa çıktıklarını öğrenme ve yazılı kaynaklara başvurma gibi bazı sosyal eylemler yer alır (Sonmaz, 2002).

Bireyin kişilerarası problemleri çözebilmede önüne çıkan engelleri aşabilmesi ve problem yaşadığı kişiyi anlayabilmesi ve problemi daha yapıcı bir şekilde çözebilmesi için kendini o kişinin yerine koyarak onun duygu ve düşüncelerini doğru bir şekilde anlaması ve onun hissettiklerini ona iletmesi gerekmektedir (Hoxha, 2011). İşte bu noktada empati kavramı iletişimde önemini ortaya koymaktadır.

Hayatımızın her alanında yer alan empati kavram olarak son zamanlarda daha çok karşımıza çıkmaya başlamıştır. Bir topluluk içinde yaşamamız sebebi ile sosyal bir varlık olarak her zaman çevremizdeki insanlarla iletişim kurmak durumundayız. Hem psikolojik hem de sosyal gelişimimizin sağlıklı olması için çevremizdeki insanları anlamamız gerekir. İnsanları anlamak yani empati kurmak söylendiği kadar kolay bir duygu değildir. Birini anlayabilmek için kendimizi tamamen o kişinin yerine koymalı ve olaylara onun gözüyle bakmalıyız. Tanımına bakıldı̆̆ında kendini başkasının yerine koyarak onu anlamaya çalışmak diye kolayca ifade edilen empati kurmak aslında çok zor bir duygudur (Sayar, 2008).

Empati duygu ve algıları içine alan bir süreç olduğu için bu süreçte kişi muhatap olduğu kişinin duygu ve düşüncelerini onun bakış açısıyla anlamaya çalışır. Bir kişiyle empati kurarken o kişinin yaşadığı olaya benzer olayların olduğu anılar hatırlanır ve o durumda hissedilenlerin ne olduğu karşı tarafa ifade edilir. Yapılan araştırmalara bakıldığında empatinin sosyal öğrenme teorilerine dayandırıldığı görülmektedir (Altınoluk, 2014). Bunlardan biri Hoffman'ın empati üzerine yapmış olduğu çalışmadır. Hoffman, psikanalitik sosyal öğrenme teorilerine dayalı bir empati modeli geliştirmiş olup empatiyi başka birinin duygusal durumuna uygun olarak ortaya konulan duygusal bir tepki olarak tanımlamıştır. Hoffman'a göre insanlardaki empatik gelişim basit düzeyde olsa bile bebeklikten itibaren vardır. Bunun en basit örneği de hiçbir sebebi yokken bir bebeğin ağlayan başka bir bebeğe karşılık vermesidir. Çocukluk dönemindeki empati kurma becerisi ile ergenlik dönemindeki empati kurma bece- 
rileri aynı değildir. Buradan da anlaşıldığı gibi empati bilişsel bir olgunlaşmayı da gerektirir. Empati kurma becerisi, çocukluk çağında aşamalı olarak gelişir ve ergenlik çağına gelindiğinde başkalarının duygularını anlayabilme kapasitesine ulaşır (Ayten, 2010). Kişideki empati gelişimini çocukluktan itibaren ele alırsak empatinin zamanla gelişebileceğini ya da körelebileceğini göz önünde bulundurmalıyız. Empati yeteneği olumlu bir aile, okul, arkadaş çevresi ve eğitimle geliştirilebilir (Altınoluk, 2014).

Empati teriminin anlamını bilmek empati kurmak için yeterli değildir. Empatinin davranış olarak doğru bir şekilde tamamlanabilmesi için üç unsurun gerçekleşmesi gerekir. Gelişim psikologlarının düzenlemelerine göre empati, birincisi duygusal öğrenme, ikincisi zihinsel öğrenme ve üçüncüsü davranışsal öğrenme olarak tanımlanır. Empati kurarken karşımızdakinin sadece duygularını değil davranışlarını duruma ya da olaya bakış açısını da anlarız. Empatinin tam olarak gerçekleşmesi için bu üç empati yeteneğine sahip olunması gerekir: duygusal olarak empati besleme, düşünce olarak empati besleme ve davranışsal olarak empati besleme (Tarhan, 2013).

Empati iletişimde bulunan iki taraf için de yararlı olan bir beceridir. Empatik becerileri ve eğilimleri yüksek olan ve bu yüzden diğer insanlara yardım eden kişilerin, çevreleri tarafından sevilme olasılıkları da artar (Dökmen, 2009). Empati kurulan kişi kendisinin kabul edildiğini ve kendisine karşı hoşgörülü davranıldığını gördüğünde kendine olan güveni artar. Böylece ileriki yaşantılarında zaman içinde kendisini engelleyen bazı olumsuz yaşantıları bırakarak, kendine ait bir değerler sistemi oluşturmaya başlar (Dökmen, 1988).

Değer kavramı günümüzde başta sosyal bilimler olmak üzere birçok bilim dalı tarafından çalışılan bir konudur. Değer kavramını birçok disiplini kendine göre tanımladığı için ortak bir tanım yapmak zordur (Dilmaç, Kulaksızoğlu ve Ekşi, 2007). Sosyal bilimler açısından baktığımızda değerleri bu kadar önemli yapan insan davranışlarını ele alması ve yorumlamasıdır diyebiliriz (Ulusoy ve Dilmaç, 2012). Kuşdil ve Kağıtçıbaşı (2000)'ya göre de değerler insan duygu, düşünce ve davranışlarıyla yakından ilişkili olduğu için birçok sosyal bilimciye göre insan davranışlarını açıklamada temel öneme sahiptir. Değer kavramını insani değerler bağlamında ele alırsak değeri 'insanı insan yapan özelliklere sahip olan ve in- 
sanı diğer canlılardan ayıran temel özellikleri içinde barındıran ve insanların davranışlarına yön veren inançlar bütünü' olarak ifade edebiliriz (Ulusoy ve Dilmaç, 2012).

İnsanın her davranışının altında değerleri vardır. Sahip olunan değerler inancı, bakış açısını, kültürünü ve tutumlarını sergiler. Kişinin kurduğu hayaller bile sahip olduğu değerlere göre şekillenir (Ulusoy ve Arslan, 2014). Sahip olunan değerler davranışlarımızın yönlenmesinde etkilidir. Gerçekleşmesi istenilen eylemin oluşması beklenen anda istenilen eylemle zit durumdaki tercihler de bulunur. O zamana kadar değerli sayd1ğımız ve yaşattığımız tutumlar bu tercihin gerçekleşmesini sağlar. Toplumdaki her birey davranışlarını, sahip olduğu değerlerinin şekillendirdiği tutumlar dahilinde gerçekleştirmektedir (Akarsu, 2015, Bozgeyikli, 2010).

İnsan tutum ve davranışlarına yön veren değer kavramı, bize değerlerin birçok değişkeni de yordayabileceği fikrini düşündürmektedir. Erikson (1968)' un da ifade ettiği gibi bedensel, toplumsal ve ahlaki açıdan çeşitli değişikliklerin yaşandığı ergenlik döneminde kişisel değerler davranışların ortaya konulması açısından büyük önem taşır (Şen, 2015). İlgili alanyazın incelendiğinde değer kavramının farklı değişkenler açısından incelendiği görülmüştür. Ancak ergenler ile yapılan çalışmalarda değerlerin kişilerarası problem çözme ve empatik eğilim değişkenleriyle birlikte incelendiği çalışmaya rastlanmamıştır. Bu sebepten ergenlerin problem çözme becerileri, empatik eğilimleri ve değerlerin birlikte incelendiği bir çalışma yapılması amaçlanmıştır.

\section{Yöntem}

\section{Araştırmanın Modeli}

Araştırmada, ergenlerin değer (sorumluluk, dostluk/arkadaşlık, barışçı olma, saygı, hoşgörü ve dürüstlük) empati ve kişilerarası problem çözme arasındaki yordayıcı ilişkileri ortaya koymak ve bu ilişkiden hareketle oluşturulan modeli test etmek amaçlanmıştır. Araştırmada genel tarama modelinin bir alt türü olan ilişkisel tarama modeli kullanılmıştır. İlişkisel 
tarama, iki ya da daha fazla değişken arasındaki ilişkiyi belirlemek ve neden-sonuç ile ilgili ipuçları elde etmek amacıyla yapılan araştırma modelidir (Büyüköztürk, Kılıç-Çakmak, Akgün, Karadeniz ve Demirel, 2008).

\section{Çalışma Evreni ve Grubu}

Araştırmanın evreni İstanbul da yer alan liselerdeki öğrenim gören öğrencilerden oluşmaktadır. Çalışma grubu ise, 2016-2017 Eğitim-Öğretim y1lında İstanbul il merkezinde çeşitli liselerde öğrenim görmekte olan tesadüfi örnekleme yöntemi ile seçilen lise öğrencilerinden oluşmaktadır. Çalışma grubunu ise, 323 kız, 251 erkek öğrenci oluşturmaktadır.

\section{Veri Toplama Araçları}

$\mathrm{Bu}$ araştırmada öğrencilerin insani değerlerini belirlemek amaciyla Dilmaç (2007) tarafından geliştirilen İnsani Değerler Ölçeği, empatik eğilimlerini ölçmek amacıyla Kaya ve Siyez (2010) tarafından geliştirilen KA-S_ Çocuk ve Ergenler İçin Empatik Eğilim Ölçeği, kişilerarası problem çözme becerilerini ölçmek için Çam ve Tümkaya (2007) tarafından geliştirilen Kişilerarası Problem Çözme Envanteri kullanılmıştır. Araştırmada kullanılan ölçüm araçlarının geçerlik ve güvenirlik bilgileri aşağıda sunulmuştur.

İnsani Değerler Ölçeği (IDDÖ): Ölçek, ergenlerin insani değerlerini belirlemek amacıyla Dilmaç (2007), tarafından geliştirilmiştir. Altı boyutta, 42 maddeden oluşan beşli likert tipi bir ölçektir. Ölçekten alınan puanların artması, bireylerin insani değerlere daha fazla sahip olduğunu gösterir. Ölçeğe ait iç tutarlılık katsayıları (Cronbach Alpha), "Sorumluluk" alt ölçeği için .73, "Dostluk/Arkadaşlık" alt ölçeği için .69, "Barışçı Olma" alt ölçeği için .65, "Sayg1" alt ölçeği için .67, "Dürüstlük" alt ölçeği için .69, "Hoşgörü" alt ölçeği için .70 ve 42 maddelik tüm ölçek için iç tutarlılık katsayısı ise alfa 92 bulunmuştur. Bu kararlılık katsayıları "Sorumluluk" için .73, "Dostluk/Arkadaşlık" için .91, "Barışçı Olma" için .80, "Sayg1" için .88, "Dürüstlük" için .75, "Hoşgörü" için .79 olarak bulunmuştur. Ölçeğin tümü için kararlılık katsayısı: .87 bulunmuştur (Dilmaç, 2007). 
KA-S_Çocuk ve Ergenler İçin Empatik Ĕ̆ilim Ölçeği: KA-S_Çocuk ve Ergenler için Empatik Eğilim Ölçeği Kaya ve Siyez (2010) tarafından geliştirilen Türk kültürüne özgü çocuk ve ergenlerin empatik eğilimlerini ölçmek amacı ile hazırlanmış likert-tipi dört dereceli, 13 maddeden oluşan bir ölçme aracıdır. KA-S_Çocuk Forumu'nun duygusal empati ve bilişsel empati olmak üzere iki alt boyut bulunmaktadır. Duygusal empati alt boyutundaki maddelerin faktör yükleri .60 ile .67, ait oldukları alt boyut toplam puanları ile korelasyonları .61 ile.74, ölçeğin tümünden alınan puanlar ile korelasyonları ise .55 ile .70 arasında değişmektedir. Bilişsel empati alt boyutundaki maddelerin faktör yükleri .54 ile.73, ait oldukları alt boyut toplam puanları ile korelasyonları .59 ile .72, ölçeğin tümünden alınan puanlar ile korelasyonları ise .46 ile .61 arasında değişmektedir.Yapılan madde analizinde varyansların homojen olmadığı tespit edilmiş ve madde analizi varyanslarının eşit olmadığı varsayımına göre yapılmıştır. Ölçekte yer alan tüm maddelere alt \%27'lik gruptaki bireylerin tepkileri ile üst \%27'lik gruptaki bireylerin tepkileri arasında anlamlı düzeyde fark gözlenmiştir (Kaya ve Siyez,2010). Çocuk formunun iç tutarlılığını gösteren cronbach alfa katsayısı, ölçeğin tümü için .84,. duygusal empati için .79 ve bilişsel empati alt boyutu için ise .72 bulunmuştur. Ölçeğin bir hafta arayla 100 öğrenciye uygulanması sonucu elde edilen test-tekrar test güvenirlik katsayısı ölçeğin tümü için .74, duygusal empati alt boyutu için .71 ve bilişsel empati alt boyutu için .69 olarak bulunmuştur. Test tekrar test güvenirlik çalışmasının yapıldığ 1 grubun verileri üzerinden yapılan hesaplamalarda ölçeğin tümü için cronbach alfa katsayısı .92, duygusal empati için .89 ve bilişsel empati için .84 bulunmuştur. Duygusal empati alt boyutunun puanları ile tüm test puanları arasında .96, bilişsel empati alt boyutunun puanları ile tüm ölçek puanları arasında .93, duygusal ve bilişsel empati alt boyutları arasında ise .78 korelasyon bulunmuştur (Kaya ve Siyez, 2010). Çocuk formunun yanıtlama biçimi "(1) Bana hiç uygun degil, (2) Bana biraz uygun, (3) Bana oldukça uygun ve (4) Bana tamamen uygun" seklinde dört dereceli bir yapıda düzenlenmiştir. Ölçekte olumsuz madde olmadığı için cevaplayıcı yanıtlarının puan değerleri yanıtlama biçimine paralel olarak toplanmaktadır. Ölçekten duygusal empatiyi ölçen 7 maddenin toplanmasıyla elde edilen duygusal empati alt boyutu puanı, bilişsel empatiyi ölçen 6 maddeye verilen yanıtların puanlarının toplamı ile elde edilen bilişsel empati alt boyutu puanı ve toplam 
empatik eğilim puanı olmak üzere üç ayrı puan elde edilmektedir. Duygusal empati alt boyutundan elde edilecek minimum puan 7x1=7, maksimum puan $7 \times 4=28$, bilişsel empati alt boyutundan elde edilecek minimum puan $6 \times 1=6$, maksimum puan $6 \times 4=24$, minimum toplam empatik eğilim puanı $13 \times 1=13$, maksimum toplam empatik eğilim puanı ise $13 \times 4=52$ dir. Ölçekten alınan puanlar arttıkça empatik eğilim artmakta, düştükçe empatik eğilim azalmaktadır (Kaya ve Siyez, 2010).

Kişilerarası Problem Çözme Envanteri (KPÇE): Envanter ilk olarak 18-30 yaş arası üniversite öğrencilerinin kişilerarası problem çözme yaklaşım ve becerilerini ölçmek amaciyla geliştirilmiştir (Çam ve Tümkaya, 2007). Daha sonra lise öğrencileri (15-18 yaş) (Çam ve Tümkaya, 2008), son olarak da yetişkinler (30-73 yaş) için (Çam, Tümkaya ve Yerlikaya, 2011) aracın geçerlik ve güvenirlik çalışmaları yapılmıştır. Her üç örneklemde de envanterin kullanılabileceğine ilişkin yeterli psikometrik özelliklere sahip olduğu görülmüştür. Envanter, Probleme Olumsuz Yaklaşma (POY), Yapıcı Problem Çözme (YPÇ), Kendine Güvensizlik (KG), Sorumluluk Almama (SA) ve Israrcı-Sebatkâr Yaklaşım (ISY) olarak adlandırılan beş alt ölçekten oluşmaktadır. Envanterde beş dereceli yanıt seçenekleri olan toplam 50 madde yer almaktadır. Envanterin yetişkin örnekleminde alt ölçekler için hesaplanan Cronbach Alfa iç tutarlılık katsayıları POY (.90), YPÇ (.88), KG (.68), SA (.74) ve ISY (.67) olarak bulunmuştur. Test-tekrar tekniğinde hesaplanan güvenirlik katsayıları sırasıyla; .82, .72, .71, .62 ve .69'dur. Envanterin alt ölçek puanlarının Problem Çözme Envanteri (PÇE) ve Sürekli Kaygı Ölçeği (SKÖ) puanları arasındaki ilişkilere bakılmıştır. PÇE ile ölçülen problem çözme algısının YPÇ (-.55) ve I-SY ile (-.34) pozitif yönde anlamlı ilişkileri saptanmıştır. POY (.35) ve KG ile (.24) de negatif yönde ilişkiler bulunmuş, ancak SA (.16) ile beklenen yönde olmakla birlikte anlamlı bir ilişki gözlenmemiştir. SKÖ puanının POY (r=.69), KG $(\mathrm{r}=.33)$ ve SA (r=.32) puanlarıyla pozitif yönde; YPÇ (r=- .29) puanıla da negatif yönde anlamlı ilişkileri tespit edilmiştir. Envanterin ölçüt geçerliği çalışmasında POY ve SA alt ölçeklerinde anlamlı bir farklılık olduğu ve kadınların erkeklere göre daha yüksek puanlar aldıkları gözlenmiştir. YPÇ, KG ve I-SY puanlarından ise cinsiyete göre anlamlı bir farklılık bulunmamıştır. 


\section{Verilerin Toplanması ve Analizi}

Verileri toplamak amaciyla tesadüfi örnekleme yöntemi ile belirlenen çalışma grubundaki ergenlere İnsani Değerler Ölçeği, Çocuk ve Ergenler İçin Empatik Eğilim Ölçeği, Kişilerarası Problem Çözme Envanteri (KPÇE) ve Kişisel Bilgi Formundan oluşan ölçme araçları uygulanmıştır. Araştırmada ergenlerin değer (sorumluluk, dostluk/arkadaşlık, barışçı olma, saygı, hoşgörü ve dürüstlük) empati ve kişiler arası ilişkiler arasındaki yordayıcı ilişkileri ortaya koymak ve bu ilişkiden hareketle oluşturulan modeli test etmek amaçlanmıştır. Veriler "Yapısal Eşitlik Modeli"ne göre AMOS 16 Programı kullanılarak analiz edilmiştir. Yapısal eşitlik modellemesi bir kuramsal modeli test etmek için gözlenen ve gizil değişkenler arasındaki nedensel ve karşılıklı ilişkileri ortaya koyan istatistiksel bir yaklaşımdır (Shumacker ve Lomax,2004).

\section{Bulgular}

Elde edilen son modelde $\left(\mathrm{X}^{2}=104, \mathrm{df}=22, \mathrm{p}<.001\right)$ alt exogenus, (sorumluluk, dostluk/arkadaşlık, barışçı olma, saygı, hoşgörü ve dürüstlük) yedi endogenous empati (duygusal ve bilişsel) ve kişilerarası problem çözme (Probleme Olumsuz Yaklaşma, Yapıcı Problem Çözme, Kendine Güvensizlik, Sorumluluk Almama ve Israrcı-Sebatkar) veri yer almaktadır. Modelde gösterilen yolların her biri istatistiksel olarak anlamlı bulunmuştur. The Bentler-Bonettnormed fit index (NFI), TheTucker-Lewiscoefficient fit index (TLI) ve diğer uyum indeksleri modelin oldukça iyi uyumlu olduğunu göstermiştir (Tablo 1). Modelde yer alan endogenous verileri arasındaki iki yönlü korelasyonların her biri yüksek değerlere sahiptir ve istatistiksel olarak anlamlıdır. Bu durum, çalışmada kullanılan değerler ölçeğinin alt boyutlarının sahip olduğu korelasyon değerlerinden de etkilenmektedir.

Tablo 1'de yer alan uyum değerleri incelendiğinde, $\mathrm{X}^{2} / \mathrm{sd}=4.792$, RMSEA $=0.72$, SRMR $=0.070, \mathrm{NFI}=0.91, \mathrm{CFI}=0.95, \mathrm{GFI}=0.86$, AGFI $=0.87$ ve TLI $=0.93$, olarak bulunmuştur. Genel olarak, modelin istenen düzeyde uyum değerlerine sahip olduğu anlaşılmaktadır (Bollen, 1989; Browne ve 
Cudeck, 1993; Byrne, 2010; Hu ve Bentler, 1999; Kline, 2011; Tanaka ve Huba, 1985).

Tablo 1. Yapısal Eşitlik Modelinin Uyumuna İlişkin İstatistiksel Değerler

\begin{tabular}{cccc}
\hline Ölçüm & İyi Uyum & Kabul Edilebilir Uyum & $\begin{array}{c}\text { Modelin Uyum İndeksi } \\
\text { Değerleri }\end{array}$ \\
\hline$\left(\mathrm{X}^{2} / \mathrm{sd}\right)$ & $\leq 3$ & $\leq 4-5$ & 4.792 \\
RMSEA & $\leq 0.05$ & $0.06-0.08$ & 0.72 \\
SRMR & $\leq 0.05$ & $0.06-0.08$ & 0.07 \\
NFI & $\geq 0.95$ & $0.94-0.90$ & 0.91 \\
CFI & $\geq 0.97$ & $\geq 0.95$ & 0.95 \\
GFI & $\geq 0.90$ & $0.89-0.85$ & 0.86 \\
AGFI & $\geq 0.90$ & $0.89-0.85$ & 0.87 \\
TLI & $\geq 0.95$ & $0.94-0.90$ & 0.93 \\
\hline
\end{tabular}

Test edilen tek faktörlü model Şekil 1'de gösterilmiştir. Modelde gösterilen tüm yollar 0.001 düzeyinde anlamlıdır.

Tablo 2. Ergenlerin Sahip Oldukları Değerler, Empati Eğilimleri ve Kişilerarası Problem Çözme Arasındaki Yordayıcı İlişkilerine Yönelik Model

\begin{tabular}{lllllll}
\hline $\begin{array}{l}\text { Yordayıc1 } \\
\text { Değişken }\end{array}$ & $\begin{array}{l}\text { Bağımlı } \\
\text { ken }\end{array}$ & $\begin{array}{l}\text { Değiş- } \\
\text { Etki }\end{array}$ & $\begin{array}{l}\text { Toplam } \\
\text { Etki }\end{array}$ & $\begin{array}{l}\text { Doğrudanlı } \\
\text { Etki }\end{array}$ & $\begin{array}{l}\text { Standart } \\
\text { Hata }\end{array}$ & $\begin{array}{l}\text { Kritik } \\
\text { Değer }\end{array}$ \\
\hline Değerler & Empati & 0.74 & 0.74 & 0 & 0.52 & $7.17^{*}$ \\
\hline Değerler & $\begin{array}{l}\text { Kişilerarası prob- } \\
\text { lem çözme }\end{array}$ & 0.27 & 0.27 & 0 & 0.34 & $3.47^{*}$ \\
\hline Empati & $\begin{array}{l}\text { Kişilerarası prob- } \\
\text { lem çözme }\end{array}$ & 0.39 & 0.39 & 0 & 0.29 & $3.58^{*}$ \\
\hline
\end{tabular}

${ }^{a}$ Toplam etki $=$ Doğrudan etki + Dolayll etki, ${ }^{*} p<0.01,{ }^{* *} p<0.05$.

Şekildeki model incelendiğinde, empatiyi etkileyen en önemli bağımsız değişkenin $(t=7.17, p<0.01)$ değerler değişkeni olduğu görülmektedir. $\mathrm{Bu}$ faktöre ilişkin bağlantı katsayı değeri $\beta=0.74$ olarak bulunmuştur. Erenlerin sahip oldukları değerler iler empati arasındaki yordayıcı ilişkileri incelendiğinde, pozitif yönlü doğrusal bir ilişki olduğu belirlenmiştir. Başka bir ifadeyle elde edilen bulgular, ergenlerin sahip oldukları değerlerin artmasıyla empati düzeylerinde de artma olacağını ortaya koymaktadir. 


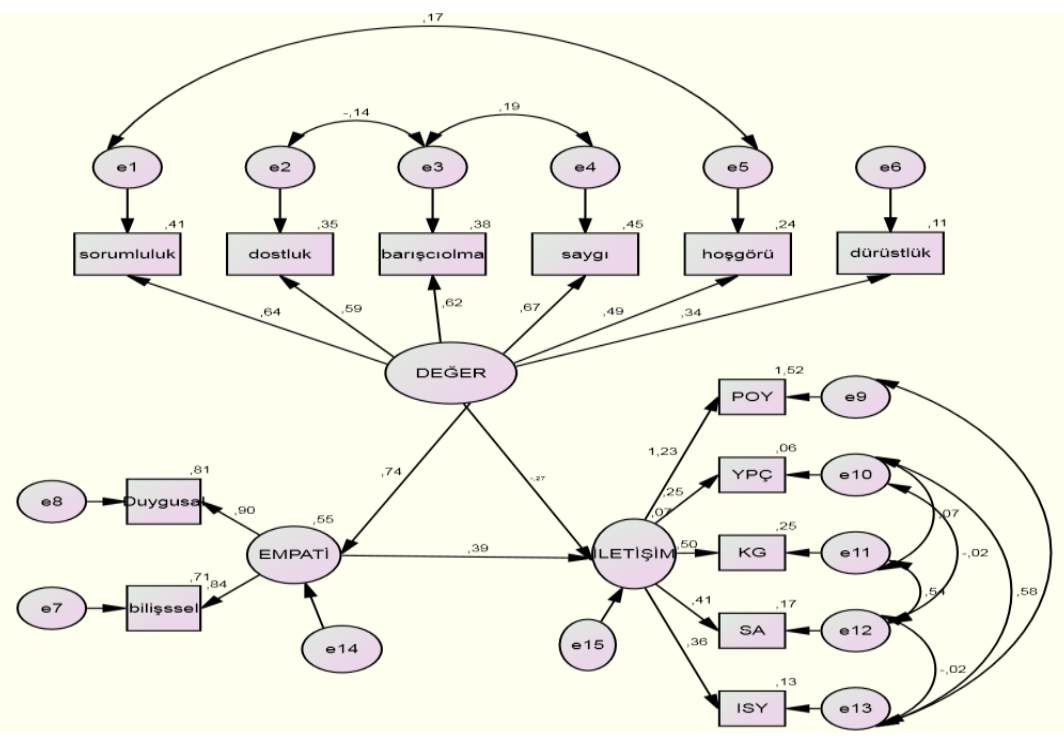

Şekil 1. Modele İlişkin Yol Analizi

Modelde kişilerarası problem çözmeyi etkileyen en önemli ikinci bağımsız değişkenin $(t=-3.47, p<0.01)$ değer değişkeni olduğu görülmektedir. Bu faktöre ilişkin bağlantı katsayı değeri $\beta=0.27$ olarak belirlenmiştir. Ergenlerin sahip oldukları değerler ile kişilerarası problem çözme arasındaki yordayıc ilişkileri incelendiğinde, pozitif yönlü doğrusal bir ilişki olduğu belirlenmiştir. Başka bir ifadeyle elde edilen bulgular, ergenlerin sahip oldukları değerlerin artması ile kişilerarası ilişkilerde problem çözme becerisinin de artma olacağını ortaya koymaktadır.

Ayrıca, test edilen modelde kişilerarası problem çözme etkileyen en önemli değişkenin $(t=3.58, p<0.01)$ empati olduğu görülmektedir. Bu faktöre ilişkin bağlantı katsayı değeri $\beta=0.39$ olarak belirlenmiştir. Ergenlerin empati ve kişilerarası problem çözme arasındaki yordayıcı ilişkileri incelendiğinde, pozitif yönlü doğrusal bir ilişki olduğu belirlenmiştir. Başka bir ifadeyle elde edilen bulgular, ergenlerin empati eğilimlerinin artmasıyla kişilerarası problem çözme becerilerinin de artacağını ortaya koymaktadir. 


\section{Tartışma}

$\mathrm{Bu}$ araştırmanın amacı, ergenlerin kişilerarası problem çözme becerileri ve empatik eğilimlerinin sahip oldukları değerler arasındaki yordayıcı ilişkiyi ortaya koymak ve bu ilişkiden hareketle oluşturulan modeli test etmektir. Yapılan literatür araştırmasında kişilerarası problem çözme, empati ve değerler değişkenlerini gerek yöntem gerekse konu bakımından birlikte inceleyen benzer bir çalışmaya rastlanmamıştır. Araştırmadan elde edilen bulgular daha önce yapılmış olan benzer nitelikteki araştırmalardan elde edilen bulgular bağlamında tartışılıp yorumlanmaya çalışılmiştır.

Araştırma bulgularına göre ergenlerin kişilerarası problem çözme becerisini etkileyen en önemli bağımsız değişkenin empati olduğu görülmektedir. Bu durum ergenlerin kişilerarası problem çözme becerilerinin sahip oldukları değerlere göre farklılaşacağını göstermektedir. Kişilerin sahip oldukları değerler arttıkça problem çözme becerilerinde de artış olacaktır. Literatüre bakıldığında kişilerarası problem çözme ve değerlerin birlikte incelendiği bir araştırmaya rastlanmamıştır. Ancak Heppner ve Petersen (1982), yaptıkları araştırmada kadın ve erkekten oluşan bir gruba altı saatlik problem çözme becerisi eğitimi verilmiş ve eğitim sonunda problem çözme becerilerinin olumlu yönde değiştiği bulgusuna varılmıştır. Verilen eğitim sonunda problem çözmede olumlu yönde değişiklik olacağı dikkate alınırsa, dolaylı yönden de olsa araştırmadan elde edilen bulgu ile literatürün birbirini desteklediği görülmektedir. Kişilerarası ilişkilerde yaşanılan problemlerin çözümü için verilen eğitimin yanında değerleri (sorumluluk, dostluk / arkadaşlık, barışçı olma, saygı, hoşgörü ve dürüstlük) ile ilgili bir artışın olmasıyla kişilerarası ilişkilerde de olumlu yönde artışın olacağı bu araştırmanın ve yaptığımız araştırmanın bulguları göstermektedir. Ağır (2007), üniversite öğrencilerinin bilişsel çarpıtma düzeyleri ile problem çözme becerileri ve umutsuzluk düzeyleri arasındaki ilişkiyi incelediği çalışmasında eğitim fakültesinde farklı bölümlerde eğitim gören öğrencilere, Bilişsel Çarpıtma Ölçeği, Problem Çözme Becerilerini Algılama Ölçeği ve Umutsuzluk Ölçeği uygulamıştır. Araştırma sonucunda öğrencilerin bilişsel çarpıtmaları artış gösterdikçe buna bağlı olarak problemleri çözme konusundaki kendilerine olan güven seviyele- 
rinde de düşüş olduğu görülmüştür. Dolayısıyla bilişsel çarpıtmalar problem çözmeyi etkilemektedir. Bu araştırma öğrencilerin problem çözme becerilerinin farklı değişkenler açısından şekillendiğini ortaya koymaktadır. Bilişsel çarpıtma gibi olumsuz duygulardaki artış problem çözmeyi ve de problem çözmeyi algılamayı olumsuz yönde etkilediği görülmektedir. İnsani değerler gibi olumlu duygulardaki artışın da problem çözmeyi olumlu yönde etkilediği görülmektedir. Bu bağlamda bu araştırmanın bulguları yapılan araştırmayı destekler niteliktedir.

Araştırmanın bir diğer bulgusuna bakıldığında kişilerarası problem çözmeyi etkileyen diğer bir değişkenin empati değişkeni olduğu görülmektedir. Ergenlerin empati eğilimlerinin artmasıyla, kişilerarası problem çözme becerilerinin de artış göstereceği öngörülmektedir. Literatüre bakıldığında empati ve kişilerarası problem çözme arasındaki ilişkiyi inceleyen Rehber ve Atıcı (2007)'nın ilköğretim ikinci kademe öğrencileriyle yaptığı çalışmaya rastlanmıştır. İlköğretim ikinci kademe öğrencilerinin empatik eğilim düzeylerine göre çatışma çözme davranışları incelenmek amacıyla yapılan bu çalışmada empatik eğilim düzeyleri yüksek olan öğrencilerin, empatik eğilim düzeyi düşük olan öğrencilere oranla problem çözme düzeyi daha yüksek bulunmuştur. Literatürdeki çalışma araştırma bulgularıyla aynı doğrultuda olup araştırmanın sonuçlarını destekler niteliktedir. Pişkin (1989), yaptığı araştırmada üniversite öğrencilerinin, empati, kaygı ve kişilerarası çatışma eğilimi arasındaki ilişkiyi incelemeyi amaçlamıştır. Araştırmanın sonucunda, öğrencilerin sürekli kaygı puanları ile çatışma puanları arasında pozitif yönde bir ilişki olduğu tespit edilirken, sürekli kaygı ve çatışma eğilimi puanları ile empatik eğilim puanları arasında negatif yönde bir ilişki olduğu tespit edilmiştir. Yapılan araştırma bulgularında empati puanları arttıkça problem çözme becerileri de artış gösterirken incelenen araştırma bulgularında ise sürekli kaygı ve çatışma eğilimi puanları arttıkça empatik eğilim puanları azalma göstermektedir. İncelenen araştırmanın bulgularını yapılan araştırma bulguları bağlamında ele alırsak empati puanları arttıkça sürekli kaygı ve çatışma eğilimi puanları da azalma gösterecektir diyebiliriz. Çatışma eğiliminin azalma göstermesi durumunda problem çözme becerilerinin de artış göstereceği düşünülmektedir. Varılan sonuçlar doğrultusunda araştırma bulguları doğrudan olmasa da dolaylı olarak yapılan araştırmanın bulgularını destekler niteliktedir. 
Yüksel (2009) tarafından yapılan çalışmada ilköğretim öğrencilerinin empati, aile işlevleri ve benlik kavramları arasındaki ilişki incelenmiştir. Araştırmanın sonucunda; aile işlevleri ile empatik beceri arasında ve empatik beceri ile iletişim, roller, duygusal tepki verebilme, davranış kontrolü ve genel fonksiyonlar arasında anlamlı ilişki bulunmuştur. Ayrıca araştırma bulgularına göre, ilköğretim öğrencilerinin empatik becerileri ile benlik saygıları arasında anlamlı ilişki olduğu görülmüştür. Literatürdeki araştırma bulguları, yapılan araştırmanın bulgularıyla doğrudan benzerlik göstermemekle birlikte empati ile ilişkilendirilen değişkenlerden elde edilen anlamlı sonuçlar bakımından araştırmanın sonuçlarıyla benzerlik göstermektedir. Literatürdeki araştırmada da yapılan araştırmada da bireylerdeki empati eğilimleri arttıkça ilişkilendirilen değişkenlerin de oranlarında artış görülmektedir. İlköğretim öğrencilerinin empati puanları arttıkça benlik saygılarında da artış olacaktır. Yapılan araştırmada ergenlerin empati puanları arttıkça problem çözme becerilerinde de artış olduğu görülmüştür. Dolayısıyla iki çalışmanın sonuçlarında empati arttıkça diğer değişkenlerin de artış gösterdiği görülmüştür.

Şahin (2007), yaptığı çalışmasında empati eğitim programının, ilköğretim 4. ve 5. sınıf öğrencilerinde zorbacı davranışlar üzerindeki etkisini ortaya koymayı amaçlamıştır. Araştırmanın sonucunda, zorbacı davranışların azalmasında, empati eğitiminin olumlu etkisi olduğu tespit edilmiştir. Verilen eğitimle öğrencilerdeki empati düzeyi artarken zorbacı davranışlar da azalma göstermektedir. Araştırmanın bulguları yapılan araştırma bulguları bağlamında değerlendirildiğinde zorbacı davranışlarda bulunmanın kişilerarası problemleri de arttıracağı öngörülmektedir. Sonuç olarak eğitimle empati düzeyinin artmasıyla zorbacı davranışlar azalırken kişilerarası problemlerde de azalma olacağı düşünülmektedir. Bu sebeplerden dolayı araştırmanın sonuçları yapılan araştırmayı destekler niteliktedir. Benzer bir çalışmayı yapan Taner Derman (2013), çalışmasında farklı sosyoekonomik düzeydeki 10-11 yaş çocuklarına uygulanan empati eğitiminin, onların saldırganlık düzeylerine etkisini incelemeyi amaçlamıştır. Araştırmanın sonucunda, uygulanan empati eğitiminin saldırganlık davranışlarını azalttığı tespit edilmiştir. İrdelenen araştırmada empati düzeyi arttıkça olumsuz bir davranış olan saldırganlıkta azalma görülürken; yapılan araştırmada ise, empati düzeyi arttıkça kişilerarası ilişkilerde de artış görülmektedir. Yapılan araştırmada empati ile kişilerarası problem 
çözme arasında pozitif yönde anlamlı bir ilişki varken; irdelenen araştırmada empati ile saldırganlık arasında negatif yönde anlamlı bir ilişki bulunmaktadır. İki araştırmada da empatinin birlikte incelendiği değişkenleri yordadığı görülmektedir. Bu araştırma bulgusunun da farklı yönlerle ele alındığında yapılan araştırmayı destekler nitelikte olduğu görülmektedir.

Araştırmanın diğer bir bulgusuna göre, empatiyi etkileyen en önemli değişkenin değerler değişkeni olduğu görülmektedir. Ergenlerin sahip oldukları değerler ile empati arasındaki yordayıcı ilişkiler incelendiğinde, pozitif yönlü doğrusal bir ilişki olduğu belirlenmiştir. Başka bir ifadeyle elde edilen bulgular, ergenlerin sahip oldukları değerlerin artması ile empati düzeylerinde de artma olacağını ortaya koymaktadır. Literatür incelendiğinde ergenlerin empatik eğilimleri ve sahip oldukları değerler arasındaki ilişkiyi inceleyen bir araştırmaya rastlanmamıştır. Benzer araştırmaların bulguları yapılan araştırmanın bulguları bağlamında irdelenmiştir.

Dilmaç (2007), bir grup fen lisesi öğrencileriyle yaptı̆̆ı araştırmasında gençlere verilen insani değerler eğitiminin, gençlerin sahip oldukları değer seviyelerinde bir değişikliğe neden olup olmadığı incelenmiştir. Araştırma sürecinde öğrenciler yedi hafta boyunca bu yönde eğitime tabi tutulmuşlardır. Araştırma sonucunda insani değerler eğitimi alan bireylerin sahip oldukları insani değer derecelerinde yükselme saptanmıştır. Dilmaç'ın yaptığı araştırmanın bulguları yapılan araştırma bulguları bağlamında irdelendiğinde eğitim sonrası öğrencilerin sahip oldukları değer seviyelerindeki artışın problem çözme becerilerinde de artışa sebep olduğu sonucunu dolaylı da olsa destekler niteliktedir.

Mutluer (2006)'in, özgüvenin oluşumunda ve özgüven düzeyinin yükselmesinde manevi değerlerin katkısını incelemeyi amaçladığı araştırmanın sonucunda manevi değerlere sahip olanların özgüven düzeylerinin diğerlerinden anlamlı derecede farklı olduğu sonucuna ulaşılmıştır. İncelenen araştırma bulgularının değerlerin özgüven düzeylerini yordaması ve yapılan araştırmada da değerlerin empatiyi yordaması açısından değerlendirildiğinde araştırmanın yapılan araştırmayı destekler nitelikte olduğu düşünülmektedir. 
Seki ve Dilmaç (2015)' nin ergen bireylerin sosyal görünüş kaygılarını ve öznel iyi oluşlarını sahip oldukları değerler açısından incelediği çalışmasının sonuçlarına göre; insani değerler alt boyutları ile öznel iyi oluş ölçeğinin alt boyutları arasında pozitif yönde anlamlı bir ilişki olduğu, sosyal görünüş kaygısı ile insani değerler ölçeğinin alt boyutları arasında da negatif yönde anlamlı bir ilişki olduğu tespit edilmiştir. İrdelenen araştırma sonuçları değişkenler arasında anlamlı ilişkiler bulunması bakımından yapılan araştırmayla örtüşmektedir. Araştırma bulgularını destekler nitelikte olan benzer bir araştırma da Büyükyıldırım ve Dilmaç (2015)'ın siber mağduriyeti sosyo-demografik değişkenler ve insani değerler açısından inceledikleri araştırmadır. Araştırma sonucunda, siber mağduriyet ile insani değerler arasında negatif yönde anlamlı bir ilişki saptanmıştır. Aynı şekilde Dilmaç ve Ekşi (2012), öğretmenlerin sahip oldukları değerler ile özgeci davranışlarını, mesleki benlik saygı perspektifinde inceledikleri araştırmada, öğretmenlerin sahip oldukları değerler ve özgeci davranışları ile mesleki benlik saygıları arasında anlamlı bir ilişki olduğu saptanmıştır. İncelenen araştırmalar konu bakımından yapılan araştırmayla aynı özelliklere sahip olmasa da değerlerle birlikte incelenen değişkenlerin bulgularında anlamlı sonuçlar tespit edilmesi bakımından araştırmayı destekler niteliktedir. 


\title{
EXTENDED ABSTRACT
}

\section{Analysis of Interpersonal Problem Solving Skills and Empathic Tendencies of Adolescents}

\author{
Selma Demir - Bülent Dilmaç \\ İstanbul Sabahattin Zaim University - Necmettin Erbakan University
}

The aim of the study is to present the predictor interrelation problem solving skills of the teenagers and the emphatetic tendency amongst the values they have and to test the model by means of this relation. The study group of the research consists of 574 students 323 of whom are girls and 251 of whom are boys attending different high-schools in central İstanbul throughout 2016-2017 academic year. The study group of the research has been chosen by random sampling method.

In the study, in order to measvie the students ability of problem solving "Interrations Problem Solving Invantery", to identify their emphatetic tendency "KA-S_Emphatetic Tendency Scale For The Kids And Adults", to identify their humanitarian values "The Humanitarian Values Scale" and "Personal Data Form" has been used.

To analyze the data as a result of the application of the measurement tools according to the "Structural Equality Model Amos 16 Programme has been used. The logic of the data abtained as a result of the statistical findings has been studied at the level of .001.

According to the result of the study, the relationship between the interrelation problem solving skills and the emphatetic tendency of the teenagers has been found statistically meaningful. In terms of this, it can be said that the more the emphatetic tendency of the teenagers increases the more the interrelation problem solving skills increase .It has been found that there is a linear and positive relationship between the emphatetic tendency and values of the teenagers. In order words, if the values the teenagers have increase, there will be an increase in the interrelation, as well. 


\section{Method}

In this study, which has a quantitative research paradigm, it is aimed to present the predictor interrelation problem solving skills of the teenagers and the emphatetic tendency amongst the values they have and to test the relationships between these variables with structural equation model. For this purpose, the research was carried out according to the relational screening model, which is a sub-type of the general screening model. General screening models are screening studies in order to reach a general judgment about the universe on a group of samples or samples taken from the universe or the universe. General screening models allow individual or relational scans (Karasar, 2015). Relational screening models are research models aiming to determine whether or not the change between two or more variables coexist or not (Karasar, 2015).

\section{Result}

When the model in the figure is examined, it is seen that the most important independent variable affecting the empathy $(t=7.17, p<0.01)$ is the values variable. The link coefficient value for this factor was found to be $\beta$ $=0.74$. When the predictive relationships between the values of the Eren and the advanced empathy were examined, a positive linear relationship was determined. In other words, the findings suggest that the increase in the values of the adolescents will increase the empathy levels.

In the model, the second most important independent variable $(t=-$ $3.47, \mathrm{p}<0.01)$ is the value variable affecting interpersonal problem solving. The link coefficient value for this factor was determined as $\beta=0.27$. When the predictive relationships between adolescents' values and interpersonal problem solving were examined, a positive linear relationship was determined. In other words, the findings suggest that increasing the values of adolescents will increase the problem solving skills in interpersonal relations.

In addition, the most important variable affecting the interpersonal problem solving $(\mathrm{t}=3.58, \mathrm{p}<0.01)$ was empathy. The link coefficient value for this factor was determined as $\beta=0.39$. When the predictive relationships of adolescents between empathy and interpersonal problem solving 
are examined, a positive linear relationship is determined. In other words, the findings suggest that interpersonal problem solving skills will increase with the increase of empathy tendencies of adolescents.

\section{Kaynakça / References}

Ağır, M. (2007). Üniversite öğrencilerinin bilişsel çarpıtma düzeyleri ile problem çözme becerileri ve umutsuzluk düzeyleri arasındaki ilişki. Doktora tezi, İstanbul Üniversitesi, Sosyal Bilimler Enstitüsü, İstanbul.

Akarsu, S. (2015). İlkokul (1-4) ve ortaokul (5-8) müzik ders kitaplarında yer alan şarkıların değerler bakımından incelenmesi ve değerler eğitimine ilişkin öğrenci alğları. Yayımlanmamış Doktora Tezi, Yüzüncü Yıl Üniversitesi Eğitim Bilimleri Enstitüsü, Van.

Altınoluk, H. (2014). Hemşirelerdelebelerde empatik eğilim ve becerilerin değgerlendirilmesi (Denizli Servergazi Hastanesi Örneği). Yüksek Lisans Tezi, Beykent Üniversitesi, Sosyal Bilimler Enstitüsü, İstanbul.

Anlıak, Ş., Dinçer, Ç. (2005). Okul öncesi dönemde kişilerarası bilişsel problem çözme becerilerinin geliştirilmesi. Eğitim Araştırmaları, 20, 122-134.

Ayten, A. (2010). Empati ve din. İstanbul: İz Yayıncılık.

Bollen, K.A. (1989). A new incremental fit index for general structural equation models. Sociological Methods and Research, 17 (3), 303-316.

Bozgeyikli, H.(2010) The relationship between high school students' psychological needs and human value perceptions. Procedia Social and Behavioral Sciences, 9, 1798-1804

Browne, M. W. ve Cudeck, R. (1993). Alternative ways of assessing model fit. Sage Focus Editions, 154, 136-136.

Büyüköztürk, Ş., Kılıç-Çakmak, E., Akgün, Ö. E., Karadeniz, Ş. ve Demirel, F. (2008). Bilimsel araştırma yöntemleri. Ankara: Pegem.

Büyükyıldırım, İ. ve Dilmaç, B. (2015). Siber mağdur olmanın insani değerler ve sosyodemografik değişkenler açısından incelenmesi. Değerler Ĕ̈itimi Dergisi, 13(29),7-40.

Byrne, B. M. (2010). Structural equation modeling with AMOS: Basic concepts, applications, and programming (2nd ed.). New York: Taylor and Francis.

Cüceloğlu, D. (1997). İnsan ve davranışı. İstanbul: Remzi Kitabevi. 
Çam, S. ve Tümkaya, S. (2007). Kişilerarası Problem Çözme Envanteri'nin (KPÇE) geliştirilmesi: Geçerlik ve güvenirlik çalışması. Türk Psikolojik Danışma ve Rehberlik Dergisi, 3(28), 95-111.

Çam, S. ve Tümkaya, S. (2008). Kişilerarası problem çözme envanteri lise öğrencileri formunun geçerlik ve güvenirlik çalışması. Uluslararası Insan Bilimleri Dergisi, 5(2), 1-17.

Çam, S., Tümkaya, S. ve Yerlikaya, E. (2011). Kişilerarası problem çözme envanterinin yetişkin örnekleminde geçerlik ve güvenirlik çalışması. Uluslararası İnsan Bilimleri Dergisi, 3(1), 1703-1724

Dilmaç, B. (2007). Bir grup fen lisesi öğrencisine verilen insani değerler eğitiminin insani değerler ölçeği ile sınanması. Yayımlanmamış Doktora Tezi, Selçuk Üniversitesi, Sosyal Bilimler Enstitüsü, Konya.

Dilmaç, B. ve Ekşi, H. (2012). Öğretmenlerin sahip oldukları değerlerin özgeci davranışlarının mesleki benlik saygısı açısından incelenmesi. Değerler Ĕ̆itimi Dergisi, 10(23),65-82.

Dilmaç, B., Kulaksızoğlu, A. ve Ekşi, H. (2007). An examination of the human values education program on a group of science high school students. Educational Sciences: Theory \& Practice, 7(3), 1221-1261.

Dökmen, Ü. (1988). Empatinin yeni bir modele dayanılarak ölçülmesi ve psikodrama ile geliştirilmesi. Ankara Üniversitesi Ĕ̆itim Bilimleri Fakültesi Dergisi, 21(1-2), 155-190.

Dökmen, Ü. (2009). Sanatta ve günlük yaşamda iletişim çatışmaları ve empati (40. Basım). İstanbul: Remzi Kitabevi.

Heppner, P., ve Petersen, C. (1982). The development and implications of a personal problem solving inventory. Journal of Counseling Psychology, 29, 66-75.

Hoxha, G. (2011), Arnavutluk ve Türkiye'deki üniversite öğrencilerinin kişilerarası ilişki ile problem çözme becerilerinin karşılaştırılması. Yayımlanmamış Yüksek Lisans Tezi, Selçuk Üniversitesi, Sosyal Bilimler Enstitüsü, Konya.

Hu, L. T. ve Bentler, P. M. (1999). Cutoff criteria for fit indexes in covariance structure analysis: Conventional criteria versus new alternatives. Structural Equation Modeling: A Multidisciplinary Journal, 6 (1), $1-55$. 
Kaya, A. Ve Siyez, D. (2010). KA-Sİ çocuk ve ergenler için empatik eğilim ölçeği geliştirilmesi geçerlik ve güvenirlik çalışması. Ĕ̆itim ve Bilim Dergisi, 35(156), 111-125.

Kline, R. B. (2011), Principles and practice of structural equation modeling. New York: The GuilfordPress.

Kuşdil, M.E., ve Kağıtçıbası, Ç. (2000). Türk öğretmenlerin değerler yönelimi ve Schwartz değer kuramı. Türk Psikoloji Dergisi, 15 (45), 5976.

Mutluer, S. (2006). Özgüven oluşmasında manevi değerlerin rolü. Yayımlanmamış Yüksek Lisans Tezi, Ankara Üniversitesi, Ankara.

Öğülmüş, S. (2001). Kişilerarası problem çözme becerileri ve eğitimi. Ankara: Nobel Yayınları.

Öğ̈̈lmüss, S. (2006). Kişilerarası Problem Çözme Becerileri ve Eğitimi. Ankara: Nobel Yayınları.

Pişkin, M. (1989). Empati, kaygı ve çatışma eğilimi arasındaki ilişki. Ankara Üniversitesi Ĕ̆itim Bilimleri Fakültesi Dergisi, 22 (2), 775-784.

Rehber, E. ve Atıcı, M. (2007). İlköğretim ikinci kademe öğrencilerinin empatik Eğilim düzeylerine göre çatışma çözme davranışlarının incelenmesi. Ç.Ü. Sosyal Bilimler Enstitüsü Dergisi, 18 (1), 323-342.

Sayar, K. (2008). Ruh hali. İstanbul: Timaş Yayınları.

Schumacker, R. E. ve Lomax, R. G. (2004). A Beginner's Guide to Structural Equation Modelling. London: Lawrence Erlbaum Associates, Publishers.

Seki, T. ve Dilmaç, B. (2015). Predictor relationships between the values the adolescents have and their levels of subjective well-being and social appearance anxiety: a model proposal. Education and Science, 40 (179), 57-67.

Sonmaz, S. (2002). Problem çözme becerisi ile yaratıcılık ve zekâ arasındaki ilişkinin incelenmesi. Yayımlanmamış yüksek lisans tezi, Marmara Üniversitesi, İstanbul.

Şahin, A. (2007). İlköğretim okullarında zorbacı davranışların azaltılmasına yönelik empati eğitim programının etkisinin araştırılması. Doktora Tezi, Atatürk Üniversitesi, Erzurum. 
Şen, A.S. (2015) Ergenlerin sahip olduklarn değerler ile gelecek beklentileri ve madde bağımlılı̆̆ından korunma öz-yeterliği arasındaki yordayıcı ilişkiler. Yüksek lisans tezi, Necmettin Erbakan Üniversitesi, Eğitim Bilimler Enstitüsü, Konya.

Tanaka, J. S. ve Huba, G. J. (1985). A fit index for covariance structure models under arbitrary GLS estimation. British Journal of Mathematical and Statistical Psychology, 38(2), 197-201.

Taner Derman, M. (2011). Farklı sosyoekonomik düzeylerdeki 10-11 yaş çocuklarına uygulanan empati eğitim programının saldırganlık düzeyleri üzerindeki etkisi. Doktora tezi, Uludağ Üniversitesi, Bursa.

Tarhan, N. (2013). Toplum psikolojisi. İstanbul: Timaş Yayınları.

Ulusoy, K. ve Arslan, A. (2014). Değerli bir kavram olarak "değer ve değerler eğitimi" R. Turan ve K. Ulusoy (Ed.) Farklı yönleri ile değerler eğitimi. Ankara: Pegem Akademi.

Ulusoy, K. ve Dilmaç, B.(2012). Değerler eğitimi.(1.Baskı).Ankara: Pegem Akademi.

Yüksel, A. (2009). İlköğretim 5. sınıf öğrencilerinin empatik becerileriyle aile işlevleri ve benlik kavramları arasındaki ilişkinin incelenmesi. Pamukkale Üniversitesi Eğitim Fakültesi Dergisi, 25(25), 153165.

Yüksel, Ç. (2008). Üniversite öğrencilerinin kişilerarası ilişkilerde yaşadıkları problemleri çözme becerilerinin belirlenmesi. Yayımlanmamış Yüksek Lisans Tezi, Selçuk Üniversitesi, Konya.

\section{Kaynakça Bilgisi / Citation Information}

Demir, S. ve Dilmaç, B. (2019). Ergenlerin kişilerarası problem çözme becerileri ve empatik eğilimlerinin sahip oldukları değerler açısından incelenmesi. OPUS-Uluslararası Toplum Araştırmaları Dergisi, 11(18), 134-156. DOI: 10.26466/opus.517581. 